\title{
Tracking platyhelminth parasite diversity from freshwater turtles in French Guiana: First report of Neopolystoma Price, 1939 (Monogenea: Polystomatidae) with the description of three new species
}

Louis H. Du Preez ${ }^{1,2^{*}}$, Mathieu Badets ${ }^{1}$, Laurent Héritier ${ }^{1,3,4}$ and Olivier Verneau ${ }^{1,3,4}$

\begin{abstract}
Background: Polystomatid flatworms in chelonians are divided into three genera, i.e. Polystomoides Ward, 1917, Polystomoidella Price, 1939 and Neopolystoma Price, 1939, according to the number of haptoral hooks. Among the about 55 polystome species that are known to date from the 327 modern living chelonians, only four species of Polystomoides are currently recognised within the 45 South American freshwater turtles.

Methods: During 2012, several sites in the vicinity of the cities Cayenne and Kaw in French Guiana were investigated for freshwater turtles. Turtles were collected at six sites and the presence of polystomatid flatworms was assessed from the presence of polystome eggs released by infected specimens.

Results: Among the three turtle species that were collected, no polystomes were found in the gibba turtle Mesoclemmys gibba (Schweigger, 1812). The spot-legged turtle Rhinoclemmys punctularia (Daudin, 1801) was infected with two species of Neopolystoma Price, 1939, one in the conjunctival sacs and the other in the urinary bladder, while the scorpion mud turtle Kinosternon scorpioides (Linnaeus, 1766) was found to be infected with a single Neopolystoma species in the conjunctival sacs. These parasites could be distinguished from known species of Neopolystoma by a combination of morphological characteristics including body size, number and length of genital spines, shape and size of the testis. They were also differentiated at the molecular level using the cox 1 gene marker. Based on morphological and genetic evidences, three new species are described herein, namely Neopolystoma cayensis n. sp. and Neopolystoma guianensis n. sp. from the bladder and the conjunctival sacs of R. punctularia, respectively, and Neopolystoma scorpioides n. sp. from the conjunctival sacs of K. scorpioides. However the monophyly of Polystomoides and Neopolystoma is still questioned regarding their phylogeny based on a dataset comprising four concatenated genes, namely, 18S, 28S and 12S rRNA genes and cox1.

Conclusions: In addition to these being the first chelonian polystomes to be reported and described from French Guiana, they represent the first polystomes from the hosts K. scorpioides and R. punctularia and the first representatives of Neopolystoma from South America. Chelonian polystomes now require an in-depth morphological study to reconcile the taxonomy of the genera with species evolution.
\end{abstract}

Keywords: French Guiana, Freshwater turtle, Kinosternon scorpioides, Mesoclemmys gibba, Rhinoclemmys punctularia, Polystomatidae, Neopolystoma

\footnotetext{
* Correspondence: louis.dupreez@nwu.ac.za

1 Unit for Environmental Sciences and Management, North-West University,

Potchefstroom 2520, South Africa

${ }^{2}$ South African Institute for Aquatic Biodiversity, Somerset Street,

Grahamstown 6139, South Africa

Full list of author information is available at the end of the article
} 


\section{Background}

While freshwater makes up less than $1 \%$ of the earth's surface, it supports at least 100,000 animal species, approximately $9.5 \%$ of the animal diversity $[1,2]$. As a starting point for conservation of the freshwater biodiversity, a comprehensive map grounded mainly on fish taxonomic studies was developed to design world's freshwater ecoregions [3]. Based on fish species richness and endemicity, several areas were identified as being of significant importance, including large portions of the Amazon basin, among which the Guianas ecoregion [3]. Besides its exceptional richness in freshwater fishes [3], this ecoregion also exhibits a great diversity of freshwater turtles with ten species known to date [4]. These include the matamata turtle Chelus fimbriata (Schneider, 1783), the scorpion mud turtle Kinosternon scorpioides (Linnaeus, 1766), the gibba turtle Mesoclemmys gibba (Schweigger, 1812), the Guyanan toad-headed turtle Mesoclemmys nasuta (Schweigger, 1812), the big-headed sideneck turtle Peltocephalus dumerilianus (Schweigger, 1812), the Guianan shield side-necked turtle Phrynops tuberosus (Peters, 1870), the twist-necked turtle Platemys platycephala (Schneider, 1792), the giant South American river turtle Podocnemis expansa (Schweigger, 1812), the yellow-spotted river turtle Podocnemis unifilis Troschel, 1848 and the spot-legged turtle Rhinoclemmys punctularia (Daudin, 1801).

Globally turtles are known to be very sensitive to modifications of their environment. They are often among the first vertebrates to disappear from impacted or altered habitats [5] and, as a result, they represent one of the most endangered groups of animals [6, 7]. Of the 327 recognised species of extant chelonians (turtles and tortoises) that are distributed throughout the most hospitable ecoregions [4], $63 \%$ are considered threatened [6]. The main reasons for the decline is degradation and loss of habitat, but overexploitation for the food market [8], pet trade [9], biological invasions [10-12] and diseases [13, 14] are also contributing causes. Freshwater turtles are indeed hosts to a wide variety of pathogens and parasites representing all major parasitic groups, including viruses [15], bacteria [16], blood parasites [17] and helminths [18, 19]. Among them, the Polystomatidae (Platyhelminthes: Monogenea) comprises 25 genera of which three, i.e. Polystomoides Ward, 1917, Polystomoidella Price, 1939 and Neopolystoma Price, 1939 infect freshwater turtles [20]. Only about 55 polystome species are known to date within chelonians, which represents approximately $25 \%$ of all known extant polystomes. Chelonian polystomes are worldwide distributed and form a clade that might have originated 178 million years ago, following a switch from caecilians to primitive freshwater turtles [21]. They would have secondarily diversified within hosts as a consequence of plate tectonics, co-divergences, turtle dispersal followed by host switching, intra-host speciation or a mixture of all these events [21]. Regardless of the scenarios involved in host-parasite diversification, these parasites are mostly host- and site-specific [22]. However, they appear to be less specific following host releases, which has been demonstrated in confined and natural environments after translocation of American freshwater turtles, especially red-eared sliders Trachemys scripta elegans (Wied, 1939) [23-25].

Since the trade of sliders was banned in Europe in 1997 [9], an increasing number of disparate freshwater turtles globally appeared in the pet trade, providing a pool of new species susceptible to be introduced into natural environments and pose a high risk for European wetlands due to climate matching [9]. As the pet trade is growing, the list of traded turtles may change rapidly in response to supply and demand [9]. Hence, there is an urgent need to assess the parasite diversity of freshwater turtles in their area of origin before new species of parasites are introduced with their native hosts in novel environments. Due to the high diversity of turtles in the Guianas that could be potentially sold as pets in Europe and some other non-European countries, our first survey of platyhelminth parasites took place in this ecoregion. We first concentrated in French Guiana freshwater environments to collect and examine freshwater turtles and their platyhelminth parasites. We report and describe hereafter three yet unknown chelonian polystomes from two host species, K. scorpioides and R. punctularia.

\section{Methods}

\section{Host sampling}

During the period 9-23 April 2012, several swampy areas and ponds near Cayenne and Kaw in French Guiana were investigated for freshwater chelonians. Site A (4.89205N, 52.34643W), site B (4.90149N, $52.35767 \mathrm{~W})$, site C $(4.82301 \mathrm{~N}, \quad 52.34115 \mathrm{~W})$, site D $(4.66997 \mathrm{~N}, 52.30560 \mathrm{~W})$ and site E $(4.87901 \mathrm{~N}$, $52.25644 \mathrm{~W})$ were all water bodies in and around Cayenne, while site F $(4.87082 \mathrm{~N}, 52.33678 \mathrm{~W})$ was a forested pond on the road to the town of Kaw. Crayfish traps baited with pork or ox liver were anchored to the vegetation to ensure they did not roll into the deeper water. They were left out overnight and placed in such a way as to allow turtles to surface and breathe when trapped. Captured animals were removed from traps the following day and placed individually in plastic tubs containing water about $50 \mathrm{~mm}$ deep and covered with shelving to keep tubs cool and dark and to prevent turtles from escaping.

\section{Parasite sampling}

The day after turtle's isolation, the water was poured through two plankton sieves with respective mesh size 
of 500 and $100 \mu \mathrm{m}$. The $500 \mu \mathrm{m}$ sieve retained course debris and most of the faeces while the $100 \mu \mathrm{m}$ sieve retained parasite eggs. The content of the $100 \mu \mathrm{m}$ sieve was then washed into a Petri dish and inspected for the presence of polystome eggs using a Nikon SMZ 645 dissecting microscope. Turtles for which no parasite eggs were detected were screened on a second and third day and, if no polystome eggs were detected, animals were released at the point of collection. Turtles to be dissected were killed by means of a lethal injection of $0.5 \mathrm{ml}$ Uthapent (sodium pentabarbitone) diluted with $4.5 \mathrm{ml}$ water. The urinary bladder and all reproductive and excretory ducts, as well as the oral and nasal cavities and conjunctival sacs under the eyelids, were examined for polystomes. All visible parasites were removed, after which the host tissue was placed in hot $70 \%$ ethanol and vigorously shaken to detach any immature parasites that might have been overlooked. Live parasites were immediately placed in a drop of water on a specimen glass slide and briefly heated from below with a butane lighter until they relaxed and stopped moving. They were fixed in $10 \%$ neutral buffered formalin under very gentle coverslip pressure and permanently mounted. Some polystome eggs were also placed in dechlorinated water in cryo vials but failed to develop. Finally, sub-adult and mature specimens earmarked for molecular studies were fixed in molecular grade $70 \%$ ethanol.

\section{Whole mount preparation, morphology and morphometry}

Polystomes were washed free of fixative and stained overnight in a weak solution of acetocarmine, dehydrated, cleared in xylene and mounted in Canada balsam. Specimens were examined using a Nikon Eclipse E800 compound microscope as well as a Nikon AZ100 (Nikon, Netherlands). Body and organs were measured using the Nikon NIS elements software program as well as marginal hooklets that were located in mature and immature parasites. All measurements are given in micrometres as the range followed by the mean in parentheses. Drawings, based on photographs taken of type-material, were prepared using Adobe Illustrator software.

\section{Molecular methods}

Polystome specimens were dried, crushed and incubated at $55{ }^{\circ} \mathrm{C}$ for one hour in $150 \mu \mathrm{l}$ of $10 \%$ suspension Chelex 100 sodium (Sigma-Aldrich, L'Isle d'Abeau Chesnes, France) and proteinase $\mathrm{K}$ at a final concentration of $1 \mathrm{mg} / \mathrm{ml}$. The enzymatic reaction was stopped at $100{ }^{\circ} \mathrm{C}$ for 15 min and DNA was kept at $4{ }^{\circ} \mathrm{C}$ until PCR amplification. Four molecular markers were investigated for genetic analyses: (i) the complete $18 \mathrm{~S}$ rRNA gene was amplified in two overlapping fragments of about $1 \mathrm{~kb}$ each, with the primers forward F18 (5'-ACC TGG TTG
ATC CTG CCA GTA G-3') and reverse 18RG (5'-CTC TCT TAA CCA TTA CTT CGG-3') on the one hand and with the primers forward 18 F3 (5'-GGA CGG CAT GTT TAC TTT GA-3') and reverse IR5 (5'-TAC GGA AAC CTT GTT ACG AC-3') on the other; (ii) partial nuclear $28 \mathrm{~S}$ rRNA gene was also amplified in two overlapping fragments of about $1 \mathrm{~kb}$ and $500 \mathrm{bp}$ each, with the primers forward LSU5' (5'-TAG GTC GAC CCG CTG AAY TTA AGC A-3') and reverse IR16 (5'-ATT CAC ACC CAT TGA CTC GCG-3') on the one hand and with the primers forward IF15 (5'-GTC TGT GGC GTA GTG GTA GAC-3') and reverse LSU3' (5'-TAG AAG CTT CCT GAG GGA AAC TTC GG-3') on the other; (iii) a portion of the mitochondrial $12 \mathrm{~S}$ rRNA gene of about $470 \mathrm{bp}$ was amplified with the primers forward 12SpolF1 (5'-YVG TGM CAG CMR YCG CGG YYA-3') and reverse 12SpolR1 (5'-TAC CRT GTT ACG ACT TRH CTC-3'); (iv) a fragment of the mitochondrial cytochrome $c$ oxydase subunit 1 ( $\operatorname{cox} 1)$ gene of about 350 bp was amplified with the primers forward L-CO1p (5'-TTT TTT GGG CAT CCT GAG GTT TAT-3') and reverse H-Cox1R (5'-AAC AAC AAA CCA AGA ATC ATG-3'). PCR amplifications were conducted following the procedure described in [21]. All PCR products were purified using the kit Wizard SV Gel and PCR Clean-Up System (Promega, Charbonnières-les-Bains, France) and sent to the company Genoscreen (Lille, France) for sequencing with the PCR primers. Chromatograms were finally examined with the software Geneious (Saint Joseph, Missouri, USA) to verify all substitutions along sequences.

\section{Sequence alignments and phylogenetic analyses}

$18 \mathrm{~S}$ and $28 \mathrm{~S}$ sequences were aligned regarding the secondary structure of nuclear rRNAs of chelonian polystomes and subsequent alignments defined by Héritier et al. [21]. Inversely, $12 \mathrm{~S}$ and cox 1 sequences were aligned using Clustal W [26] implemented in the program MEGA, version 5 [27], under default parameters. In order to explore the relationships of the chelonian polystomes collected during the present study, sequences reported in [21, 24, 28-30] (GenBank accession numbers 18S: AJ228788, AJ228792, FM992696-FM992699, KR856126KR856139; 28S: AF382065, FM992702-FM992706, KR8 56145-KR856158; 12S: KR856100-KR856119; cox1: Z83 005, Z83007, Z83009, Z83011, FR822527, FR822529FR822531, FR822534, FR822553, FR822555, FR822570, FR822587, FR822601, FR822603, FR822604, FR828360, KR856175-KR856177), as well as the newly generated sequences reported here (see below), were included in a global phylogenetic analysis that was performed following the procedure of Héritier et al. [21]. A global alignment was first inferred with the concatenated sequences recovered from 23 fully described or undescribed species. Regions 
not sequenced, which concerned particularly the $18 \mathrm{~S}$ rRNA gene and the $500 \mathrm{bp}$ fragment of the $28 \mathrm{~S}$ rRNA gene of the polystome collected from the bladder of $K$. scorpioides, were treated as missing data. Ribosomal nuclear sequences were partitioned into two discrete regions, i.e. stems and loops, while $12 \mathrm{~S}$ and cox 1 sequences were considered as two other distinct partitions. A doublet model was considered for the stem partition and a $\mathrm{GTR}+\mathrm{I}+\mathrm{G}$ for the loops. A GTR + I $+\mathrm{G}$ was also selected independently for the two last partitions following the Akaike Information Criterion (AIC) implemented in Modeltest 3.06 [31]. A Bayesian analysis was run using MrBayes 3.04b [32], with four chains running for one million generations and sampled every 100 cycles. The consensus tree was then drawn after removing the first 1,000 trees (10\%) as the 'burn-in' phase to obtain the Bayesian posterior probability for each association. Nanopolystoma tinsleyi, which was recognised as the sister group of chelonian polystomes after phylogenetic analysis [21], was used as the outgroup (GenBank accession numbers 18S: KR856124; 28S: KR856142; 12S: KR856077; cox1:KR856164).

\section{Genetic divergences within chelonian polystomes}

Kimura 2-parameters (K2P) distances were estimated from the whole cox 1 dataset using MEGA, version 5, to assess genetic divergences among chelonian polystomes. Results were discussed in the light of the $3.4 \% \operatorname{cox} 1$ genetic divergence threshold defined by Héritier et al. [23] on chelonian polystomes.

\section{Results}

\section{Turtles and parasites collected}

The spot-legged turtle $R$. punctularia was found at all the sites except site A. Of the total sample, 23 specimens were collected at site $\mathrm{B}$, three at site $\mathrm{C}$, one at site $\mathrm{D}$, three at site $\mathrm{E}$ and 10 at site $\mathrm{F}$. The scorpion mud turtle $K$. scorpioides was found at all the sites except site E. Of the total sample, two specimens were collected at site A, one each at sites B and C, 13 at site D and four at site F. Of the total sample of the gibba turtle $M$. gibba, four specimens were collected at site D and three at site E.

Among the 68 turtles that were collected, two chelonian species were found to be infected with polystomes, i.e. R. punctularia and K. scorpioides, whereas M. gibba was uninfected. Based on the release of polystome eggs, infected turtles were euthanized and dissected to recover all polystomes. Of the $40 \mathrm{R}$. punctularia, infected animals were found at sites B and F. At site B, two out of 23 turtles released round polystome eggs, while another one released round and fusiform eggs. At site F, one of the ten turtles released both round and fusiform polystome eggs while a second one released only fusiform eggs. Of the $21 \mathrm{~K}$. scorpioides, a single turtle out of the
13 collected at site D released fusiform eggs. Based on the absence of hamuli, all parasites found in the bladder and in the conjunctival sacs of their host could be considered at that stage as belonging to Neopolystoma.

\section{Class Monogenea (van Beneden, 1858) \\ Order Polystomatidea Lebedev, 1988 \\ Family Polystomatidae Gamble, 1896}

\section{Neopolystoma cayensis $\mathrm{n}$. sp.}

Type-host: Rhinoclemmys punctularia (Daudin, 1801) (Geoemydidae Theobald, 1868).

Type-locality: Pond on the outskirts of Cayenne, French Guiana (4.87082N, 52.33678W).

Site in host: Urinary bladder.

Type-material: Morphological description based on 22 sexually mature worms. The holotype (NMB P394) and nine paratypes (NMB P395-P403) were deposited in the Parasitic Worm Collection, National Museum, Aliwal Street, Bloemfontein, South Africa.

Voucher material: Remainder of specimens were deposited in the polystome collection of the North-West University, Potchefstroom, South Africa.

Prevalence and intensity: Site B: Prevalence 13.0\%; Mean intensity 12.7. Site F: Prevalence 10.0\%; One specimen infected by 176 polystomes.

Representative DNA sequences: GenBank accession numbers: KY200986 (18S), KY200988 (28S), KY200991 (12S) and KY200994 (cox1).

ZooBank registration: To comply with the regulations set out in article 8.5 of the amended 2012 version of the International Code of Zoological Nomenclature (ICZN) [33], details of the new species have been submitted to ZooBank. The Life Science Identifier (LSID) of the article is urn:lsid:zoobank.org:pub:B55369A7-5 F88-4A7294 F2-E0CE354484A1. The LSID for the new name Neopolystoma cayensis n. sp. is urn:lsid:zoobank.org:act:A4E27E97-052E-4709-84 AD-B262A1A625D4.

Etymology: This parasite is named after Cayenne, the capital of French Guiana, where the parasite was found.

\section{Description}

[Based on 22 egg-producing adults (see Table 1 and Fig. 1a-e). No larval measurements or characters are given as eggs collected from the host failed to develop.] Body elongate, pear shaped with the widest point about two-thirds from the anterior extremity (Fig. 1a), total length 3,342-5,575 (4,139), greatest width 1,353-1,961 (1,753). Haptor length 759-1,139 (912), haptor width $1,095-1,459(1,249)$, haptor length to body length ratio 0.20-0.25 (0.22). Mouth subterminal, ventral. False oral sucker 130-356 (189) wide. Pharynx muscular, $293-401 \times 276-457 \quad(330 \times 357)$. Intestine bifurcates 
Table 1 Body morphometrics for the known species of Neopolystoma from the Neotropical realm

\begin{tabular}{|c|c|c|c|c|c|}
\hline & N. cayensis n. sp. & N. guianensis n. sp. & N. scorpioides n. sp. & N. domitilae & N. fentoni \\
\hline Body length & $3,342-5,575(4,139)$ & $2,284-3,342(2,737)$ & $1,512-1,770(1,658)$ & $4,039-4,057$ & $1,500-2,450(1,985)$ \\
\hline Body maximum width & $1,353-1,961(1,753)$ & $830-1,164(1,037)$ & 868-907 (894) & $1,320-1,722$ & $426-760(568)$ \\
\hline Haptor length & 759-1,139 (912) & 634-852 (755) & $445-511(485)$ & $1,046-1,067$ & $449-690(571)$ \\
\hline Haptor width & $1,095-1,459(1,249)$ & 784-1,014 (910) & 719-765 (735) & $1,416-1,851$ & $550-850(683)$ \\
\hline Width at vagina & $1,015-1,504(1,281)$ & 792-1,091 (989) & 837-876 (863) & - & - \\
\hline Oral sucker width & 130-356 (189) & 189-391 (290) & $240-245(242)$ & $370-450(547)$ & 240-496 (370) \\
\hline Pharynx length & 293-401 (330) & $189-260(213)$ & 170-184 (177) & $305-322$ & $156-257(216)$ \\
\hline Pharynx width & $276-457(357)$ & $226-283(252)$ & 226-231 (228) & 328 & $185-367(278)$ \\
\hline Ovary length & 140-357 (195) & 149-243 (197) & 136-187 (153) & $322-402$ & $80-245(103)$ \\
\hline Ovary width & 62-118 (88) & $71-120(97)$ & $66-71(69)$ & $112-127$ & $55-169(105)$ \\
\hline Testis length & 560-983 (762) & $364-541(437)$ & $120-142(127)$ & $450-664$ & $98-367(225)$ \\
\hline Testis width & 468-1,283 (933) & $380-527(477)$ & 246-301 (271) & 289-338 & $78-251(181)$ \\
\hline Genital bulb width & 73-129 (99) & 49 & 45 & $241-273$ & $30-83(60)$ \\
\hline Number of genital spines & $16-17$ & 8 & 8 & $20-21$ & 8 \\
\hline Genital spine length & $19-26(23)$ & 8.4-9.8 (8.9) & $5.5-8.7(7.7)$ & $55-71$ & 11 \\
\hline Number of eggs in utero & 1 & 1 & 1 & 1 & 1 \\
\hline Egg length & 209-289 (246) & 280-344 (317) & $253-279(265)$ & 305 & 245-332 (286) \\
\hline Egg width & 155-187 (165) & $127-163(148)$ & $133-156(143)$ & 177 & $122-146(136)$ \\
\hline Haptoral sucker width & $227-297(261)$ & $208-242(226)$ & $133-279(220)$ & $305-483$ & $210-326(265)$ \\
\hline $\begin{array}{l}\text { Haptor length: Body } \\
\text { length ratio }\end{array}$ & 0.22 & 0.28 & 0.29 & 0.26 & 0.29 \\
\hline $\begin{array}{l}\text { Marginal hooklet } \\
1 \text { length }\end{array}$ & $19.6-21.8(21.2)$ & $13.3-15.1(14.3)$ & $16.4-17.2(16.8)$ & 24.6 & $11.8-12.7(12.5)$ \\
\hline
\end{tabular}

without diverticula; caeca narrow, lacking anastomoses, run laterally, not confluent posteriorly, not extending into haptor. Testis single, mid-ventral, medial, posterior to ovary, flattened, lobed along outer margin with reticulated network of ducts in central area (Fig. 1a, b), 560-983 × 468-1,283 (762 × 933); large amounts of sperm observed in reticulated network. Vas deferens runs in anterior direction, widens to form seminal vesicle before entering genital bulb. Genital bulb median, ventral, posterior to intestinal bifurcation, 73-129 (99) in diameter, armed with single ring of 16-17 spines (Fig. 1c), 19-26 (23) long, tip of spine curved outwards. Ovary dextral, at $15 \%$ of body length from anterior extremity, small, $140-357 \times 62-118$ $(195 \times 88)$. Uterus short, tubular, anterior to ovary, containing single oval egg; egg capsule 209-289 × 155-187 $(246 \times 165)$. No intra-uterine development, egg operculate. Vaginae present, located about 1/3 from anterior extremity of body proper; body width at level of vagina 1,015-1,504 (1,281); body slightly indented at level of vaginae. Vitellarium in two broad lateral fields along full length of body proper except for anterior area including mouth and pharynx and posteriormost section of the body (Fig. 1a). Vitelline follicles in two lateral fields, joining in narrow strip between genital bulb and pharynx and posteriad, at level of caeca tips. Genito- intestinal canal prominent, dextral, joining intestinal caecum at level of ovary (Fig. 1a). Haptoral suckers 6, muscular, with well-developed skeletal structure inside (Fig. 1d), mean diameter 227-297 (261). Hamuli absent. Marginal hooklets (Fig. 1e) retained in mature parasites. Posteriormost marginal hooklet 1 19.6-21.8 (21.2) long; hooklets 2-8 19.4-22.3 (20.9) long.

\section{Neopolystoma guianensis n. sp.}

Type-host: Rhinoclemmys punctularia (Daudin, 1801) (Geoemydidae Theobald, 1868).

Type-locality: Pond on the outskirts of the capital Cayenne, French Guiana (4.87082N, 52.33678W).

Site in host: Conjunctival sacs of the eye.

Type-material: Eleven sexually mature worms. The holotype (NMB P404) and two paratypes (NMB P405-P406) were deposited in the Parasitic Worm Collection, National Museum, Aliwal Street, Bloemfontein, South Africa.

Voucher material: Remainder of specimens were deposited in the polystome collection of the North-West University, Potchefstroom, South Africa.

Prevalence and intensity: Site B: Prevalence 4.3\%; One specimen infected by two polystomes. Site F: Prevalence 20.0\%; Mean intensity 11.0. 


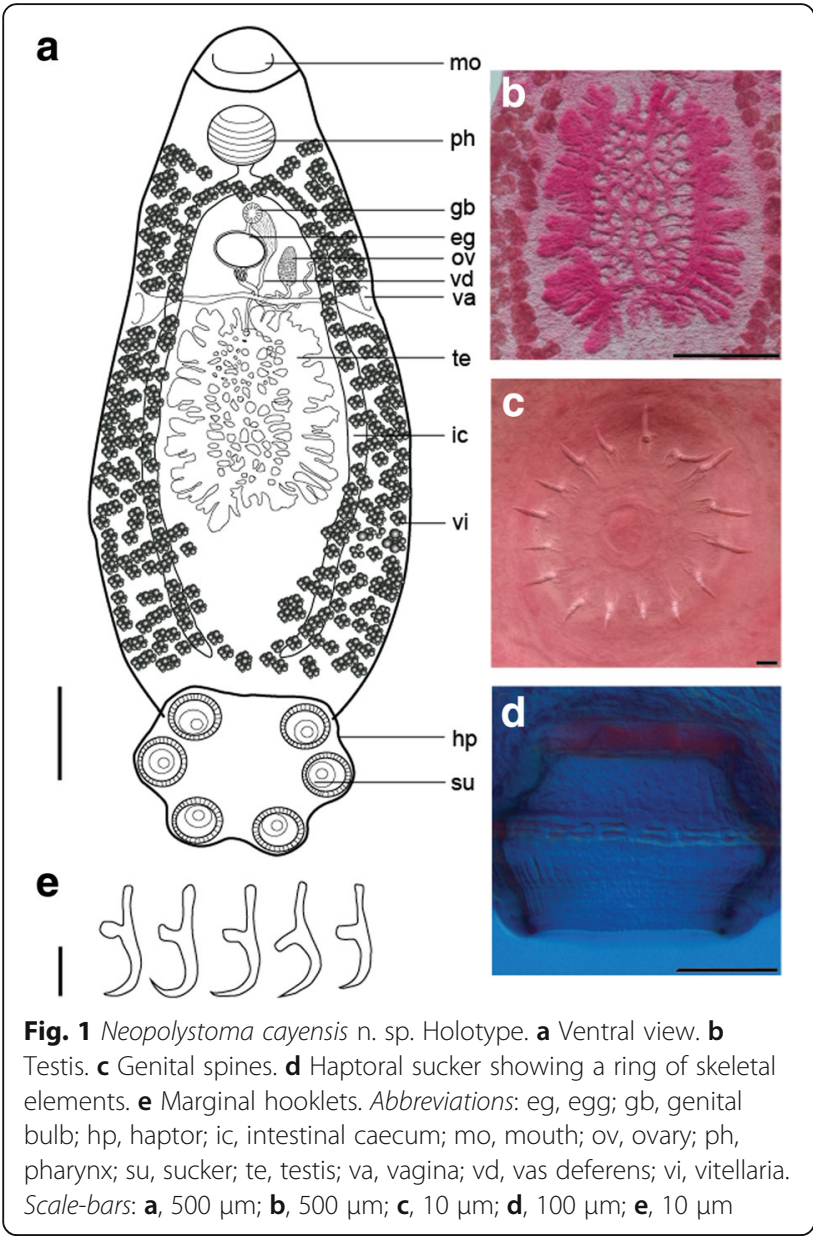

Representative DNA sequences: GenBank accession numbers: KY200987 (18S), KY200989 (28S), KY200992 (12S) and KY200995 (cox1).

ZooBank registration: To comply with the regulations set out in article 8.5 of the amended 2012 version of the International Code of Zoological Nomenclature (ICZN) [33], details of the new species have been submitted to ZooBank. The Life Science Identifier (LSID) of the article is urn:lsid:zoobank.org:pub:B55369A7-5 F88-4A7294. F2-E0CE354484A1. The LSID for the new name Neopolystoma guianensis n. sp. is urn:lsid:zoobank.org:act:1BDAA38D-D657-4DCC-9539-F5BDEFB463B8.

Etymology: This parasite is named after French Guiana.

\section{Description}

[Based on 11 egg-producing adults (see Table 1 and Fig. 2a-e). No larval measurements or characters are given as eggs collected from the host failed to develop.] Body elongate, spindle shaped, with widest point in middle of body proper, total length 2,284-3,342 (2,737), greatest width 830-1,164 $(1,037)$. Haptor length $634-852$ (755), haptor width 784-1014 (910), haptor length to body length ratio $0.24-0.31(0.28)$. Mouth subterminal, ventral.

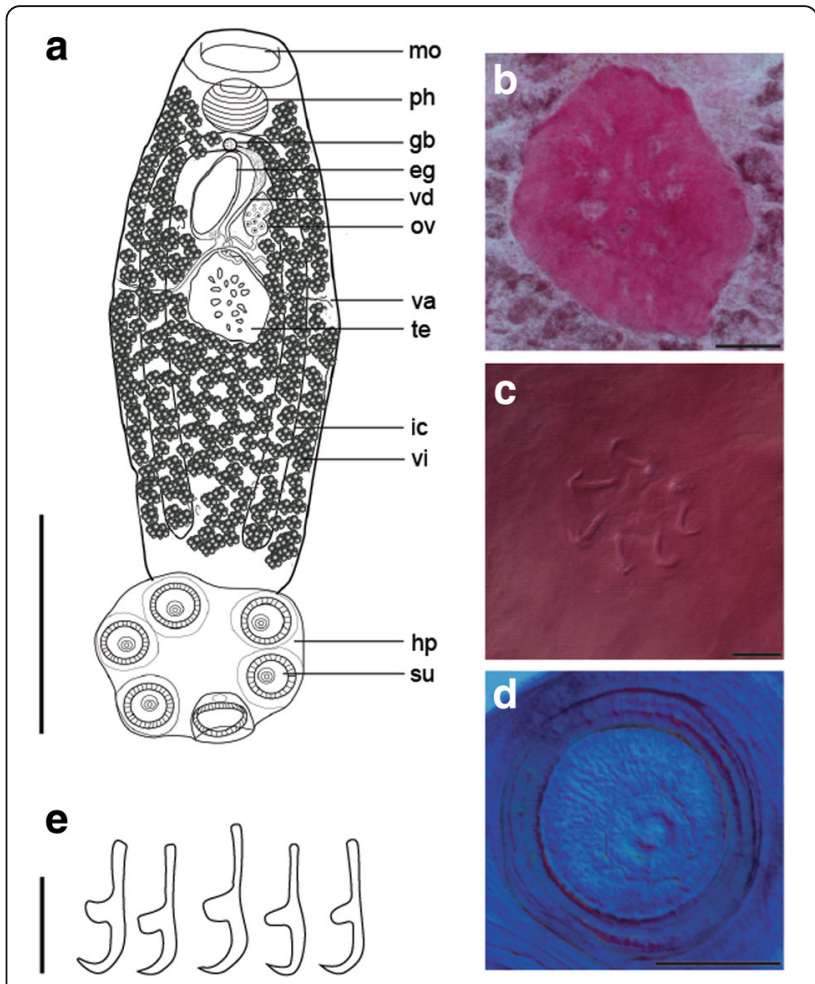

Fig. 2 Neopolystoma guianensis n. sp. Holotype. a, Ventral view. b, testis. c genital spines. $\mathbf{d}$ haptoral sucker showing a ring of skeletal elements. e marginal hooklets. Abbreviations: eg, egg; gb, genital bulb; hp, haptor; ic, intestinal caecum; mo, mouth; ov, ovary; ph, pharynx; su, sucker; te, testis; va, vagina; vd, vas deferens; vi, vitellaria. Scale-bars: a, 1,000 $\mu \mathrm{m} ; \mathbf{b}, 100 \mu \mathrm{m} ; \mathbf{c}, 10 \mu \mathrm{m} ; \mathbf{d}, 100 \mu \mathrm{m} ; \mathbf{e}, 10 \mu \mathrm{m}$

False oral sucker prominent, 189-391 (290) wide. Pharynx $189-260 \times 226-283(213 \times 252)$. Intestine bifurcates without diverticula; caeca narrow, lacking anastomoses, run laterally, not confluent posteriorly, not extending into haptor. Testis single, spherical, compact (Fig. 2b), midventral, medial, posterior to ovary (Fig. 2a), 364-541 $\times$ 380-527 $(437 \times 477)$. Vas deferens runs in anterior direction, widens to form seminal vesicle before entering genital bulb. Genital atrium median, ventral, posterior to intestinal bifurcation, 49 in length, with 8 spines, 8.4-9.8 (8.9) long (Fig. 2c); spines slightly curved. Ovary about $1 / 3$ from the anterior extremity, dextral, small, $149-243 \times 71-120 \quad(197 \times 97)$. Uterus short, tubular, anterior to ovary, contained one fusiform egg in utero (all specimens studied); egg capsule 280-344× 127-163 $(317 \times 148)$. No intrauterine development observed, eggs operculate. Vaginae present, located nearly in middle of body proper; body width at the level of vagina 792-1,091 (989). Vitellarium extends from just behind pharynx throughout most of body proper except for area around gonads and posteriormost part of body proper. Genito-intestinal canal obscured by testis, dextral, joining intestinal caecum posterior to ovary 
(Fig. 2a). Live specimens were extremely flexible and able to extend the body proper to nearly double its length. Posterior section of body proper appears to be especially very flexible and elastic. Haptoral suckers 6, muscular, with well-developed skeletal structure inside (Fig. 2d), mean diameter 208-242 (226). Hamuli absent. Marginal hooklets retained in adult parasites (Fig. 2e). Posteriormost marginal hooklet 1 13.3-15.1 (14.3) long; hooklets 2-8 12.9-14.3 (13.9) long.

\section{Neopolystoma scorpioides n. sp.}

Type-host: Kinosternon scorpioides (Linnaeus, 1766) (Kinosternidae Agassiz, 1857).

Type-locality: Forest pond along the Cayenne-Kaw road south of the town of Roura, French Guiana (4.66997N, $52.30560 \mathrm{~W})$.

Site in host: Conjunctival sacs of the eye.

Type-material: Three sexually mature worms. The holotype (NMB P407) and two paratypes (NMB P408-P409) were deposited in the Parasitic Worm Collection, National Museum, Aliwal Street, Bloemfontein, South Africa.

Prevalence and intensity: Site D: Prevalence 7.7\%; One specimen infected by four polystomes.

Representative DNA sequences: GenBank accession numbers: KY200990 (28S), KY200993 (12S) and KY2 00996 (cox1).

ZooBank registration: To comply with the regulations set out in article 8.5 of the amended 2012 version of the International Code of Zoological Nomenclature (ICZN) [33], details of the new species have been submitted to ZooBank. The Life Science Identifier (LSID) of the article is urn:lsid:zoobank.org:pub:B55369A7-5 F88-4A7 2-94 F2-E0CE354484A1. The LSID for the new name $N$. scorpioides n. sp. is urn:lsid:zoobank.org:act:7852C6EAFDEC-435 F-9319-5379747 F7099.

Etymology: This parasite is named after the host $K$. scorpioides.

\section{Description}

[Based on three egg-producing adults (see Table 1 and Fig. 3a-e). No larval measurements or characters are given as eggs collected from the host failed to develop.] Body oval, total length 1,512-1,770 (1,658), greatest width 868-907 (894), width at vagina 837-876 (863). Haptor length 445-511 (485), haptor width 719-765 (735), haptor length to body length ratio 0.29. Mouth subterminal, ventral. False oral sucker prominent, 240-245 (242) wide. Pharynx 170-184× 226-231 (177 × 228). Intestine bifurcates without diverticula; caeca lacking anastomoses, not confluent posteriorly, not extending into haptor. Testis single, compact, oval (Fig. 3b), mid-ventral, medial and posterior to ovary, 120-142 × 246-301 (127 × 271). Vas deferens runs in anterior direction, widens to

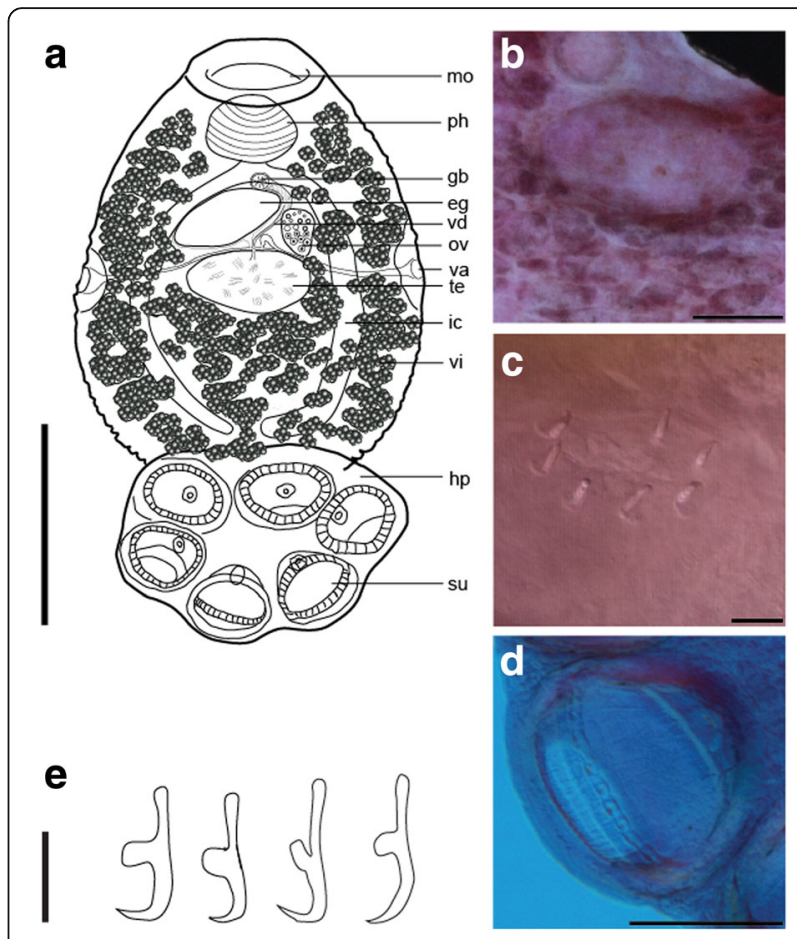

Fig. 3 Neopolystoma scorpioides n. sp. Holotype. a Ventral view. b testis of holotype. $\mathbf{c}$ genital spines. $\mathbf{d}$ haptoral sucker showing a ring of skeletal elements. e marginal hooklets. Abbreviations: eg, egg; gb, genital bulb; hp, haptor; ic, intestinal caecum; mo, mouth; ov, ovary; ph, pharynx; su, sucker; te, testis; va, vagina; vd, vas deferens; vi, vitellaria. Scale-bars: a, $500 \mu \mathrm{m} ; \mathbf{b}, 100 \mu \mathrm{m} ; \mathbf{c}, 10 \mu \mathrm{m} ; \mathbf{d}, 100 \mu \mathrm{m}$; e, $10 \mu \mathrm{m}$

form seminal vesicle before entering genital bulb. Genital atrium median, ventral, posterior to intestinal bifurcation, 45 in diameter, with eight straight spines with curved tips (Fig. 3c), 5.5-8.7 (7.7) long. Ovary dextral, at $44 \%$ of body length from anterior extremity, 136-187 × 66-71 (153× 69). Uterus short, tubular, anterior to ovary, containing only one fusiform egg; egg capsule $253-279 \times 133-156$ $(265 \times 143)$. No intrauterine development, eggs operculate. Vitellarium extends from just behind pharynx throughout most of body proper except for area around gonads and posteriormost part of body proper. Genito-intestinal canal obscured by testis, dextral, joining intestinal caecum posterior to ovary (Fig. 3a). Haptoral suckers 6, muscular, with well-developed skeletal structure inside (Fig. 3d), mean diameter 133-279 (220). Hamuli absent. Marginal hooklets (Fig. 3e) retained in adult parasites. Posteriormost marginal hooklet 1 16.4-17.2 (16.8) long; hooklets 2-8 13.4-14.8 (14.2) long.

Molecular, phylogenetic and genetic divergence analyses One worm of each of N. cayensis n. sp., N. guianensis n. sp. and $N$. scorpioides $\mathrm{n}$. sp. were used for molecular studies. With the exception of the 18S rRNA and a portion of the $28 \mathrm{~S}$ rRNA genes that failed to amplify for $N$. 
scorpioides n. sp., we obtained sequences for all three polystomes. The Bayesian tree showed with high confidence values the phylogenetic relationships within chelonian polystomes (Fig. 4). N. guianensis n. sp. and $N$. scorpioides n. sp. were sister species and nested in Clade 3, according to Héritier et al. [21]. Estimates of cox1 genetic divergences between these two polystomes were about $15.5 \%$, which was well beyond the threshold of $3.4 \%$ defined for chelonian polystomes by Héritier et al. [23]. These two polystomes thus belonged to separate species. Conversely, $N$. cayensis n. sp. was nested in Clade 2 according to Héritier et al. [21]. Estimates of $\operatorname{cox} 1$ genetic divergences between this polystome and the former two species were 22.2 and $26.1 \%$, respectively, and ranged from 16.9 to $20.3 \%$ with the most closely related species. These results also indicated that this polystome belonged to another species.

\section{Discussion}

\section{Diagnosis}

Whereas two Neopolystoma species were known from Central America and so in the Neotropical realm, namely Neopolystoma fentoni Platt, 2000 from Costa Rica and Neopolystoma domitilae (Caballero, 1938) from Mexico, the three Neopolystoma species described herein are the first members of the genus recorded from South America. Neopolystoma cayensis n. sp. differs from other members of the genus reported in the Neotropical realm by a combination of characters. Based on the body length, $N$. cayensis n. sp., with a length of 3,342-5,575
$(4,139) \mu \mathrm{m}$, is significantly longer than $N$. guianensis $\mathrm{n}$. sp. with a length of 2,284-3,342 (2,737) $\mu \mathrm{m}, N$. scorpioides $\mathrm{n}$. sp. with a length of $1,512-1,770(1,658)$ $\mu \mathrm{m}$ and $N$. fentoni with a length of 1,500-2,450 (1,985) $\mu \mathrm{m}$. If it is not significantly longer than $N$. domitilae $(4,039-4,057 \mu \mathrm{m})$, the latter is significantly longer than $N$. guianensis n. sp. and N. scorpioides $\mathrm{n}$. sp. Based on the genital spine number, $N$. cayensis $\mathrm{n}$. sp. with 16-17 spines differs from $N$. domitilae with 20-21 spines and from the three polystomes of the conjunctival sacs, namely $N$. guianensis n. sp., $N$. scorpioides n. sp. and $N$. fentoni, which all have eight spines. Based on the genital spine length, $N$. cayensis $n$. sp. with spine length of 19-26 (23) $\mu \mathrm{m}$ also differs from $N$. domitilae with spine length of $55-71 \mu \mathrm{m}, N$. fentoni with spine length of $11 \mu \mathrm{m}, N$. guianensis $\mathrm{n}$. sp. with spine length of 8.4-9.8 (8.9) $\mu \mathrm{m}$ and $N$. scorpioides $\mathrm{n}$. sp. with spine length of 5.5-8.7 (7.7) $\mu \mathrm{m}$. Concerning testis length, it varies between all Neopolystoma species. Neopolystoma cayensis $\mathrm{n}$. $\mathrm{sp}$. has a testis length of 560-983 (762) $\mu \mathrm{m}, N$. guianensis $\mathrm{n}$. sp. a testis length of 364-541 (437) $\mu \mathrm{m}, N$. domitilae a testis length of 450-664 $\mu \mathrm{m}, N$. fentoni a testis length of 98-367 (225) $\mu \mathrm{m}$ and $N$. scorpioides $\mathrm{n}$. sp. a testis length of 120-142 (127) $\mu \mathrm{m}$.

\section{Diversity of chelonian polystomes in South America}

In spite of the considerable diversity of South American amphibians [34] and chelonians [4], relatively few polystomes were reported from South America [20, 22]. Currently, 16 polystomes are known from anurans, three

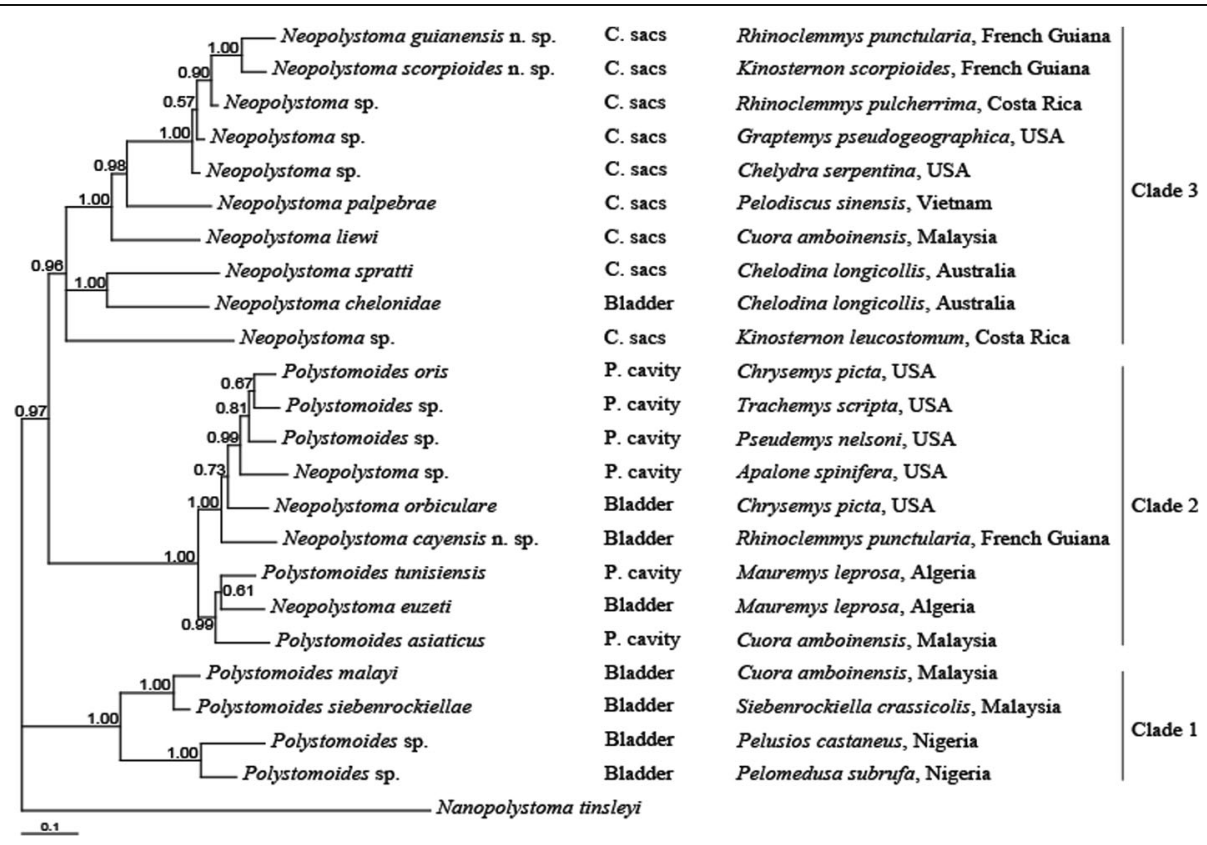

Fig. 4 Bayesian tree inferred from the analysis of four concatenated genes. Numbers at nodes correspond to Bayesian posterior probabilities. Abbreviations: C. sacs, conjunctival sacs; P. cavity, pharyngeal cavity 
from caecilians and six from chelonians. Turtle polystomes include Polystomoides coronatum (Leydi, 1888) from Trachemys dorbigni (Duméril \& Bibron, 1835); Polystomoides uruguayensis Mané-Garzon \& Gil, 1961 from Phrynops hilarii (Duméril \& Bibron, 1835); Polystomoides fuquesi Mané-Garzon \& Gil, 1962 from P. hilarii; Polystomoides rohdei Mané-Garzon \& Holcman-Spector, 1968 from T. dorbigni; Polystomoides brasiliensis Vieira, Novelli, Souza \& de SouzaLima, 2008 from Hydromedusa maximiliani (Mikan, 1820) and Phrynops geoffroanus (Schweigger, 1812); and Polystomoides magdalenensis Lenis \& Garcia-Prieto, 2009 from Trachemys callirostris (Gray, 1856). All of these were reported from the pharyngeal cavity of their host. If we assume, as stated by Verneau [22], that chelonian polystomes are host- and site-specific in natural environments on the one hand and that turtle species are infected by no more than three polystome species depending of their ecological niche on the other, it is likely that a single polystome species rather than two really infect each of the two freshwater turtles $T$. dorbigni and $P$. hilarii, respectively. We should therefore consider only four Polystomoides species occurring within South American chelonian hosts. However, this must be further confirmed from genetic analyses of the cox 1 marker. The description of three new species in this study, namely $N$. cayensis $\mathrm{n}$. sp., $N$. guianensis $\mathrm{n}$. sp. and $N$. scorpioides n. sp. is a novelty as it is the first statement of polystomes from the bladder and conjunctival sacs of South American turtles. Although Avila et al. [35] reported the presence of a Neopolystoma species from Mesoclemmys vanderhaegei (Bour, 1973) in Brazil, nothing was mentioned about the ecological niche of this undescribed parasite. We can, therefore, consider that Neopolystoma is here accounted for the first time in South America. Knowing that we surveyed in just two weeks 68 specimens of freshwater turtles belonging to three distinct species and in the light of the rich diversity of chelonians in South America [4], it is very likely that vast numbers of polystomes remain undescribed.

\section{Status of Neopolystoma and Polystomoides}

Whereas the three chelonian polystome genera Neopolystoma, Polystomoides and Polystomoidella are distinguished on the basis of the presence of hamuli, i.e. Neopolystoma has no hamuli, Polystomoidella has a single pair of hamuli and Polystomoides has two pairs, it is now well established that Neopolystoma and Polystomoides, at least, are not monophyletic [21, 36]. The phylogenetic study by Héritier et al. [21] showed that the absence of hamuli on the one hand and the presence of two pairs of hamuli on the other were not true morphological synapomorphies for Neopolystoma and Polystomoides, respectively. Whereas Neopolystoma and
Polystomoides are known from the conjunctival sacs, bladder and pharyngeal cavity of their host [22], Polystomoidella is known only from the bladder of its host. Regarding our phylogenetic tree, all Neopolystoma spp. from the conjunctival sacs could form a distinct clade, i.e. Clade 3 (Fig. 4), if the possibility is considered of an accidental switch of vials or a mislabelled tissue when sampling Neopolystoma chelodinae (MacCallum, 1918), which infects the bladder of Chelodina longicollis (Shaw, 1794) from Australia and which is nested within that clade. Based on morphology, Neopolystoma spp. from the conjunctival sacs do not differ significantly from any other chelonian polystomes from the bladder and pharyngeal cavity. However, parasites of the conjunctival sacs are the only chelonian polystomes that do not lay spherical eggs. They indeed produce fusiform or spindleshaped eggs [24]. We can therefore hypothesise that this particular shape of egg could be a synapomorphy for the group of polystomes infecting the conjunctival sacs. However, this needs to be further validated after a more in-depth study of polystomes collected from Australian turtles, particularly $N$. chelodinae from C. longicollis. Clade 1 of the Bayesian tree contains only polystomes with two pairs of hamuli, i.e. Polystomoides spp. that infect the bladder of their host. Although species of Polystomoides can be also found within Clade 2, all of them infect the pharyngeal cavity of their host. Hence, this suggests that polystomes with two pairs of hamuli occurring in the bladder of their host belong to a separate lineage (Clade 1). On the opposite, Clade 2 of the Bayesian tree contains species of both genera, with Polystomoides spp. infecting the pharyngeal cavity and Neopolystoma spp. infecting either the pharyngeal cavity or the bladder. Because there is no trend in the number of hamuli and the ecological niche of the parasites nested in Clade 2, the morphology of these species should be revisited in order to establish whether morphological synapomorphies for that particular clade really exist.

\section{The need for the study of helminth diversity}

In the pursuit of conservation efforts in any vertebrate group, it is important to understand the broad biological context of that group, including its parasite diversity. While some parasites are harmless to chelonian hosts, others may adversely affect host behaviour, general fitness and chances of survival $[13,14]$. Furthermore, in a changing world where animals are sold for pets, some species may invade new environments and bring with them a great number of parasite species. Concerning turtles, Meyer et al. [25] and Héritier et al. [23] investigated the polystome richness among two European freshwater turtles, Mauremys leprosa (Schweigger, 1812) and Emys orbicularis (Linnaeus, 1758), respectively. They documented a greater polystome diversity than 
expected assuming a high degree of host- and sitespecificity [22]. Surprisingly, a few polystome species reported within populations of $M$. leprosa and $E$. orbicularis were also found in American hosts that had never been recorded in the European freshwater environments of investigation. Meyer et al. [25] and Héritier et al. [23] showed that these parasite species were in fact introduced into natural wetlands following the introduction of the American red-eared slider T. s. elegans. Because that turtle is among the most common exotic turtle species in captivity, it would act as a reservoir of numerous parasite species [24], and, once released into freshwater habitats, it would have served as a carrier of parasites, as for instance Neopolystoma sp. 4 (haplotype H18), Polystomoides sp. 1 (haplotype H16) and X. sp (haplotype H36), which would have been transmitted to native turtles across European freshwater environments [23, 25]. Since T. s. elegans was banned from the commercial trade in Europe, some other turtle species were identified in pet markets. Among the 17 chelonian species that were offered for sale by the French society "La Ferme Tropicale" on July 2016 07th (https://www.lafermetropicale.com), 13 freshwater species were from the USA, Central America, Asia and Africa. A similar situation was found on the online Reptimania society (http://www.reptimania.com). On July 2016 07th, numerous exotic chelonian species were indeed offered for sale, among which $R$. pulcherrima. Hence, this demonstrates the need to document and describe as fast as possible the helminth diversity of freshwater turtles in their home range before their parasites invade novel freshwater environments following the introduction and possible release of new exotic chelonian species.

\section{Conclusions}

Based on morphological and molecular characters, three new polystome species are described therein from freshwater turtles of French Guiana, i.e., K. scorpioides and $R$. punctularia. These are the first representatives of Neopolystoma in South America. Nevertheless, regarding our global phylogenetic analysis of chelonian polystomes, the revision of Polystomoides and Neopolystoma taxonomy within the Polystomatidae is required. In fine, as more and more South American turtle species are considered in the international pet trade, our study indicates the importance to survey parasite diversity within chelonians in their home range, before they are released in new freshwater environments.

\section{Acknowledgments}

We are indebted to the National Research Foundation of South Africa and the Ministère des Affaires Étrangères Français for financial support. We are also thankful to Philippe Gaucher for his assistance in the field and to two anonymous reviewers for their helpful comments.

\section{Funding}

The study was financed through the South Africa - France Protea program, a Science and Technology Research Collaboration project between the National Research Foundation of South Africa and the Ministère des Affaires Étrangères Français.

\section{Availability of data and material}

Sequences for all three polystomes were deposited in the GenBank database under accession numbers KY200986 (18S), KY200988 (28S), KY200991 (12S) and KY200994 (cox1) for N. cayensis n. sp., KY200987 (18S), KY200989 (28S), KY200992 (12S) and KY200995 (cox1) for N. guianensis n. sp. and KY200990 (28S), KY200993 (12S) and KY200996 (cox1) for N. scorpioides n. sp.. The typespecimens were deposited in the Parasitic Worm Collection,

National Museum, Aliwal Street, Bloemfontein, South Africa under accession numbers (NMB P394-P403) for N. cayensis n. sp., (NMB P404-P406) for N. guianensis n. sp. and (NMB P407-P409) for N. scorpioides n. sp.

\section{Authors' contributions}

MB initiated the research visit to French Guiana, obtained the collection permits and played an important role during the fieldwork with LDP and OV. $\mathrm{LH}$ played a key role in conducting the molecular and phylogenetic analyses under the supervision of OV. LDP performed the morphological analyses and, finally, LDP and OV took the leadership in writing the manuscript. All authors read and approved the final manuscript.

\section{Competing interests}

The authors declare that they have no competing interests.

\section{Consent for publication}

Not applicable.

\section{Ethics approval and consent to participate}

This study was conducted under ethical clearance no 01D04 (Taxonomy and biology of polystomatid flatworms) issued by the ethical commission of the North-West University, Potchefstroom, South Africa.

\section{Author details}

${ }^{1}$ Unit for Environmental Sciences and Management, North-West University, Potchefstroom 2520, South Africa. ${ }^{2}$ South African Institute for Aquatic Biodiversity, Somerset Street, Grahamstown 6139, South Africa. ${ }^{3}$ University of Perpignan Via Domitia, Centre de Formation et de Recherche sur les Environnements Méditerranéens, UMR 5110, F-66860 Perpignan, France. ${ }^{4}$ CNRS, Centre de Formation et de Recherche sur les Environnements Méditerranéens, UMR 5110, F-66860 Perpignan, France.

Received: 9 August 2016 Accepted: 12 January 2017

Published online: 31 January 2017

\section{References}

1. Balian EV, Segers H, Lévèque C, Martens K. The freshwater animal diversity assessment: an overwiew of the results. Hydrobiologia. 2008;595:627-37.

2. Dudgeon D, Arthington AH, Gessner MO, Kawabata ZI, Knowler DJ, Lévêque $C$, et al. Freshwater biodiversity: importance, threats, status and conservation challenges. Biol Rev. 2006;81:163-82.

3. Abell R, Thieme ML, Revenga C, Bryer M, Kottelat M, Bogutskaya N, et al. Freshwater ecoregions of the world: A new map of biogeographic units for freshwater biodiversity conservation. BioScience. 2008:58:403-14.

4. Van Dijk PP, Iverson JB, Rhodin AGJ, Shaffer HB, Bour R. Turtles of the world, 7th edition: Annotated checklist of taxonomy, synonymy, distribution with maps, and conservation status. Chelonian Res Monogr. 2014;5:329-479.

5. Bour R. Global diversity of turtles (Chelonii; Reptilia) in freshwater. Hydrobiologia. 2008;595:593-8.

6. Buhlmann KA, Akre TSB, Iverson JB, Karapatakis D, Mittermeier RA, Georges $A$, et al. A global analysis of tortoise and freshwater turtle distributions with identification of priority conservation areas. Chelonian Conserv Biol. 2009;8:116-49.

7. Böhm M, Collen B, Baillie JE, Bowles P, Chanson J, Cox N, et al. The conservation status of the world's reptiles. Biol Conserv. 2013;157:372-85.

8. Turtle Conservation Fund. A global action plan for conservation of tortoises and freshwater turtles. Strategy and Funding Prospectus 2002-2007. 
Washington: Conservation International and Chelonian Research Foundation; 2002

9. Masin S, Bonardi A, Padoa-Schioppa E, Bottoni L, Ficetola GF. Risk of invasion by frequently traded freshwater turtles. Biol Invasions. 2014;16:217-31.

10. Cadi A, Joly P. Competition for basking places between the endangered European pond turtle (Emys orbicularis galloitalica) and the introduced red-eared slider (Trachemys scripta elegans). Can J Zool. 2003;81:1392-8.

11. Polo-Cavia N, López P, Martin J. Competitive interactions during basking between native and invasive freshwater turtle species. Biol Invasions. 2010;12:2141-52.

12. Pearson $\mathrm{SH}$, Avery HW, Spotila JR. Juvenile invasive red-eared slider turtles negatively impact the growth of native turtles: Implications for global freshwater turtle populations. Biol Conserv. 2015;186:115-21.

13. Schumacher J. Selected infectious diseases of wild reptiles and amphibians. J Exot Pet Med. 2006;15:18-24.

14. Gibbons PM, Steffes ZJ. Emerging infectious diseases of chelonians. Vet Clin Exot Anim. 2013;16:303-17.

15. Jungwirth N, Bodewes R, Osterhaus ADME, Baumgärtner W, Wohlsein P. First report of a new alphaherpesvirus in a freshwater turtle (Pseudemys concinna concinna) kept in Germany. Vet Microbiol. 2014;170:403-7.

16. Readel AM, Phillips CA, Goldberg TL. Prevalence of Salmonella in intestinal mucosal samples from free-ranging red-eared sliders (Trachemys scripta elegans) in Illinois. Herpetol Conserv Biol. 2010;5:207-13.

17. Telford Jr SR, Norton TM, Moler PE, Jensen JB. A new Haemogregarina species of the alligator snapping turtle, Macrochelys temminckii (Testudines: Chelydridae), in Georgia and Florida that produces macromeronts in circulating erythrocytes. J Parasitol. 2009;95:208-14.

18. McAllister CT, Barger MA, Stuart JN. Neoechinorhynchus emyditoides Fisher, 1960 (Acanthocephala: Neoechinorhynchidae) from the Mexican plateau slider, Trachemys gaigeae (Testudines: Emydidae) in New Mexico, U.S.A. Comp Parasitol. 2008;75:135-7.

19. Zelmer DA, Platt TR. Structure and similarity of helminth communities of six species of Australian turtles. J Parasitol. 2008;94:781-7.

20. Morrison C, Du Preez LH. Turtle polystomes of the world: Neopolystoma, Polystomoidella \& Polystomoides. Saarbrücken: VDM Verlag Dr. Müller; 2011.

21. Héritier L, Badets M, Du Preez LH, Aisien MS, Lixian F, Combes C, Verneau O. Evolutionary processes involved in the diversification of chelonian and mammal polystomatid parasites (Platyhelminthes, Monogenea, Polystomatidae) revealed by palaeoecology of their hosts. Mol Phylogenet Evol. 2015;92:1-10.

22. Verneau O. Origine et évolution des monogènes Polystomatidae, parasites d'amphibiens et de chéloniens d'eau douce. Perpignan: HDR dissertation, Université de Perpignan Via Domitia; 2004

23. Héritier L, Valdeón A, Sadaoui A, Gendre T, Ficheux S, Bouamer S, et al. Introduction and invasion of the red-eared slider and its parasites in freshwater ecosystems of southern Europe: risk assessment for the European pond turtle in wild environments. Biodiv and Conserv. (In press).

24. Verneau O, Palacios C, Platt T, Alday M, Billard E, Allienne JF, Basso C, Du Preez $\mathrm{LH}$. Invasive parasite threat: parasite phylogenetics reveals patterns and processes of host-switching between non-native and native captive freshwater turtles. Parasitology. 2011;138:1778-92.

25. Meyer L, Du Preez L, Bonneau E, Héritier L, Quintana MF, Valdeón A, et al. Parasite host-switching from the invasive American red-eared slider, Trachemys scripta elegans, to the native Mediterranean pond turtle, Mauremys leprosa, in natural environments. Aquat Invasions. 2015;10:79-91.

26. Thompson JD, Higgins DG, Gibson TJ. CLUSTAL W: improving the sensitivity of progressive multiple sequence alignment through sequence weighting, position-specific gap penalties and weight matrix choice. Nucl Acids Res. 1994;22:4673-80

27. Tamura K, Peterson D, Peterson N, Stecher G, Nei M, Kumar S. MEGA5: molecular evolutionary genetics analysis using maximum likelihood, evolutionary distance, and maximum parsimony methods. Mol Biol Evol. 2011;28:2731-9

28. Littlewood DTJ, Rohde K, Clough KA. Parasite speciation within or between host species? Phylogenetic evidence from site-specific polystome monogeneans. Int J Parasitol. 1997;27:1289-97.

29. Littlewood DTJ, Rohde K, Clough KA. The phylogenetic position of Udonella (Platyhelminthes). Int J Parasitol. 1998;28:1241-50.
30. Badets M, Verneau O. Origin and evolution of alternative developmental strategies in amphibious sarcopterygian parasites (Platyhelminthes, Monogenea, Polystomatidae). Org Divers Evol. 2009;9:155-64.

31. Posada D, Crandall KA. Modeltest: testing the model of DNA substitution. Bioinformatics. 1998;14:817-8.

32. Huelsenbeck JP, Ronquist F. MRBAYES: Bayesian inference of phylogenetic trees. Bioinformatics. 2001;17:754-5.

33. International Commission on Zoological Nomenclature. Amendment of articles 8, 9, 10, 21 and 78 of the International Code of Zoological Nomenclature to expand and refine methods of publication. Zootaxa. 2012;3450:1-7.

34. Frost DR. Amphibian Species of the World: an Online Reference. Version 6.0 Electronic Database accessible at http://research.amnh.org/herpetology/ amphibia/index.html. American Museum of Natural History, New York, USA. Assessed 07 July 2016

35. Avila RW, Brito ES, Barrella TH, Strussmann C, Silva RJ. Endoparasites new to the Neotropical freshwater turtle, Mesoclemmys vanderhaegei (Bour 1973) (Testudines, Chelidae), from central Brazil. Panam J Aquat Sci. 2010;5:478-80.

36. Verneau O, Bentz S, Sinnappah ND, Du Preez LH, Whittington I, Combes C. A view of early vertebrate evolution inferred from the phylogeny of polystome parasites (Monogenea: Polystomatidae). Proc R Soc B. 2002;269:535-43.

\section{Submit your next manuscript to BioMed Central and we will help you at every step:}

- We accept pre-submission inquiries

- Our selector tool helps you to find the most relevant journal

- We provide round the clock customer support

- Convenient online submission

- Thorough peer review

- Inclusion in PubMed and all major indexing services

- Maximum visibility for your research

Submit your manuscript at www.biomedcentral.com/submit
Biomed Central 